\title{
What is Alive and What is Dead in the Theory of Corporatism
}

\author{
Lucio Baccaro
}

\begin{abstract}
The term 'corporatism' simultaneously designates a particular interest group structure, characterized by monopolistic, centralized and internally nondemocratic associations, and a particular policy-making process, also known as 'concertation' or 'social partnership'. This paper argues that structure and process may no longer be closely associated. By focusing on the Irish and Italian cases, it shows that concertation is perfectly compatible with a non-corporatist structure of the interest representation system. Inter-and intra-organizational co-ordination remains important for the viability of concertation. However, it can be achieved, even in relatively fragmented systems like the Irish and the Italian, through alternative mechanisms relying on democracy and discussion.
\end{abstract}

\section{Introduction}

For the past thirty years, scholars interested in the relationship between industrial relations systems and the political sphere have turned to corporatist theory as a major source of inspiration. In the last decade, however, the emergence of so-called 'social pacts' in countries - e.g. Ireland, Italy, Portugal, South Africa, South Korea, Spain — which appear to lack the institutional and organizational preconditions once deemed necessary for these kinds of policies to succeed, has cast doubt on the theory's relevance for current practice (Regini 1997; Fejertag and Pochet 1997, 2000; O'Donnell 2001; Berger and Compston 2002; Molina and Rhodes 2002; Katz 2004).

This paper distinguishes between corporatism as a particular structure of the interest representation system, characterized by monopolistic, centralized and internally non-democratic associations, and 'concertation' or 'social partnership', as a particular policy-making process. While logically different, these two constructs often blend into one another — so much so that a single term, '(neo-)corporatism', is generally used to designate both. The paper 
argues that, while the policy-making process (concertation) is very much alive, as illustrated by developments in various countries, mostly but not exclusively European, corporatism as an interest representation structure may possibly be dead.

This is not to say that intra- and inter-organizational cohesion and coordination - which figured prominently in the early corporatist literature (Schmitter and Lehmbruch 1979; Berger 1981; Lehmbruch and Schmitter 1982; Goldthorpe 1984; Katzenstein 1985; Visser 1990) - no longer matter for the success of concerted policy-making. These are still important features. However, they can be achieved in different ways. In particular, organizational co-ordination can be brought about through different mechanisms from those that corporatist theory focused upon - mechanisms relying on democracy and discussion, rather than hierarchy and coercion (Baccaro 2002b).

This has important consequences for policy-making. Concertation appears to be compatible with a wider variety of organizational structures than was previously believed. Some of these alternative structures seem to have normative advantages over the traditional corporatist model, since they are less at odds with basic democratic rights like freedom of association and collective bargaining, or freedom of expression within associations (see Schmitter 1983; Cawson 1986; Streeck 1994; Schreiner 1994).

In this paper, the argument that concertation can safely rest on a noncorporatist structure of the interest representation system (if democratic mechanisms of organizational co-ordination are activated) is illustrated by focusing on two of the most unexpected as well as successful recent cases of social concertation, Ireland and Italy. Section 2 contains a brief overview of corporatist theory. Section 3 reviews the trajectory of social partnership in Ireland and Italy. Section 4 discusses the particular aggregative and deliberative mechanisms through which the Irish and Italian labour movements solved the problem of intra- and inter-organizational co-ordination. Section 5 reconstructs the internal process of social partnership in the two countries. Section 6 provides a compact version of the argument. Section 7 concludes by examining the political economic determinants of concertation.

\section{An overview of corporatist theory}

The early corporatist literature featured two different definitions of corporatism. The first, by Philippe Schmitter, emphasized the particular organizational characteristics of the interest representation system. This definition went as follows:

Corporatism can be defined as a system of interest representation in which the constituents units are organized into a limited number of singular, compulsory, non-competitive, hierarchically ordered and functionally differentiated categories, recognized or licensed (if not created) by the state and granted a deliberate representational monopoly within their respective categories in exchange for observing 
certain controls on their selection of leaders and articulation of demands and supports. (Schmitter 1979 [1974]: 13)

The second definition, by Gerhard Lehmbruch, focused on the particular process through which public policy was formed:

Corporatism is more than a peculiar pattern of articulation of interests. Rather, it is an institutionalized pattern of policy formation in which large interest organizations cooperate with each other and with public authorities not only in the articulation (or even 'intermediation') of interests, but — in its developed forms - in the 'authoritative allocation of values' and in the implementation of such policies. (Lehmbruch 1979[1977]: 150)

Clearly, the two definitions covered different ground. To avoid confusion, Schmitter (1982: 263) proposed to call corporatism the 'first' and concertation the 'second' definition (see also Regini 1997: 269; Compston 2002: 3; Molina and Rhodes 2002: 306). At the same time, corporatism and concertation appeared to be closely linked empirically — so closely that a single term ('neo-corporatism') ended up designating both. One set of features, those related to the interest representation system, was regarded as the structural precondition for the other. In other words, without interest representation structures that approximated the corporatist ideal type of 'monopolistic, hierarchically ordered, officially recognized, clearly delimited associations' (Schmitter 1979: 13), concertation would not work properly. The failures of social contracts in Italy and the UK, as well as in Ireland in the late 1970s, appeared neatly to illustrate the truth of this assertion (Regini 1984; Hardiman 1988). ${ }^{1}$

Concertation seemed to work best when the structure of the interest representation system resembled the structure of the European corporatist societies of the 1920s and 1930s (a period in which societal interests were not allowed to organize freely). This implied that a limited number of actors (ideally, one) should be allowed to sit on each side of the bargaining table. Also, these actors should be able to impose their will on their lower-level affiliates, both at the industry, and more importantly, at the workplace levels.

The focus of the corporatist literature was, at least initially, overwhelmingly on trade unions. ${ }^{2}$ In fact, the policies that corporatism dealt with were such that workers were asked to give up sure benefits in exchange for uncertain future rewards. The unions' ability to deliver worker acquiescence or compliance with these policies was regarded as key. The organizational characteristics of unions were examined from two different perspectives. The first was horizontal co-ordination. Multiple unions were considered a problem because of their tendency to engage in leapfrogging, i.e. demanding a little more than the others had already obtained. The higher the number of unions, the lower the concentration, and the higher the likelihood of leapfrogging (Golden 1993: 439; Iversen 1999: 48-57). The second perspective was vertical control. Lower level structures with ample operational autonomy were also a problem because of the tendency to exceed (or worse, ignore) the terms 
negotiated by the peak levels (Schmitter 1979: 13; Streeck 1982: 32; Traxler et al. 2001: 107).

In practice, achieving horizontal co-ordination and vertical control meant limiting two kinds of workers' freedom: freedom of association, and freedom of expression within associations (Lange 1983: 432-4). The workers' right to join or found alternative associations (the 'exit option') if they were dissatisfied with the policies pursued by the organization to which they were affiliated (or, along similar lines, the right of a lower-level affiliate to secede from the confederation) needed to be curtailed. Hence the corporatist literature emphasized the need for monopolistic associations and compulsory or semicompulsory membership (Offe 1981; Panitch 1979). Also, the workers' ability to shape the associations' policies through the voice option had to be reduced. Decision-making power needed to be concentrated in the hand of peak-level leaders. The assumption behind this thinking was that rank-and-file workers were more myopic and/or short-term-oriented than their leaders; left to themselves, they would subscribe to policies that went against their own best interests (Streeck 1982: 71; Schumpeter 1950: 260-1).

In contrast with these theoretical premises, the recent wave of social pacts in Europe and elsewhere suggests that organizational structure (corporatism) and the policy-making process (concertation) may no longer coincide. In fact, these pacts surface and sometimes even prosper in countries - e.g. the southern European countries, Ireland, South Africa and South Korea - where the structure of the interest representation system is much more fragmented, and the disciplinary power of central echelons much more limited, than would be expected. Ireland and Italy are two cases in point. Both countries are known to lack the kind of centralized organizational capacities generally associated with corporatism (Hardiman 1988: 3; O’Donnell and O'Reardon 1997: 85; Tarantelli 1986: 348-82). Yet during the 1990s, all major policy-making was through 'social partnership' (to use the Irish terminology) or 'concertazione' (in the Italian vernacular) in these two countries.

The article now turns to explaining the apparent paradox of concertation in the absence of corporatist structure and provides a basic reconstruction of events.

\section{Social partnership in Ireland and Italy}

\section{Ireland}

From the late 1980s on, five successive social partnership agreements between government, unions and employers (with the participation of farmers and, from 1996 on, civil society organizations as well) shaped wage formation and public policy more generally in Ireland. The first social partnership agreement was the Programme for National Recovery (PNR) (1988-90). At the time this agreement was signed, government debt and the budget deficit were skyrocketing, investment was stagnant and, in spite of growing emigration, 
unemployment was rising. This perceived sense of crisis played an important role in bringing about centralization.

With the PNR, the Irish Congress of Trade Unions (ICTU) agreed to contain wage increases within limits negotiated at the national level. Also, the ICTU committed itself not to take industrial action that would result in additional cost increases for the employers. This latter clause signalled an important departure from the practice of two-tier bargaining that had characterized previous centralized agreements in the 1970s (Hardiman 1988: 80-120; Roche 1997: 179-82). In exchange, government agreed to reduce personal taxation and to preserve the real value of social welfare allowances.

During the three years covered by the PNR (1988-90), the Irish economy performed very well. GNP grew strongly (3.6 per cent per year) and led to improvements in virtually all other macroeconomic indicators. In the following years, social partnership became the backbone of Irish economic policy. Like the PNR, the Programme for Economic and Social Progress (1991-3) set wage increases for all economic sectors simultaneously. It also established that, 'exceptionally', wage increases up to 3 per cent could be negotiated at the local level as well. Not surprisingly, a sizeable proportion of local agreements implemented the 3 per cent clause. However, the employers managed to link these additional payments to workplace restructuring and productivity increases (Roche 1997: 208).

The early 1990s were difficult years for Ireland as growth subsided and unemployment began to grow again. In spite of changing economic conditions, however, the strategy of social partnership did not change. The Programme for Competitiveness and Work (PCW) (1994-6) focused on employment creation. With the PCW, the social partners continued the policy of wage moderation and further reduced the difference between gross income and take-home pay through additional tax cuts.

The Partnership 2000 (P2000) agreement (1997-9) centred on two distinct themes: the need to extend social partnership to the enterprise level, and the need to reduce social disparities and exclusion. The focus on enterprise-level partnership was based on the belief that, just as at the national level, so at the workplace level, co-operative relationships could increase competitiveness and produce mutual gains. On these themes, however, the agreement was exhortatory rather than prescriptive. Perhaps for this reason, partnership at the enterprise level does not seem to have diffused widely in Ireland (Roche and Geary 2000; Gunnigle et al. 1999).

With the 2000-2 Programme for Prosperity and Fairness (PPF), social partnership shifted its emphasis from macroeconomic policy to more supply-side-oriented policies. Unemployment was no longer the most pressing problem: labour and skill shortages were. The agreement contained a series of recommendations on issues like skill development, infrastructural investments (e.g. roads and public transportation), the provision of more affordable housing and the development of child care facilities. The PPF agreement also devoted a significant amount of attention to social policies. For example, social welfare benefits and child benefits were increased. The 
wage portion of the agreement was similar to that of the past and continued the policy of wage moderation.

In economic terms, the Irish social partnership appears to be a big success. Between 1988 and 2000, real GDP grew by 132 per cent in Ireland, compared with 45 per cent in the United States and 32 per cent in the European Union. Centralized wage determination seems to have greatly increased the competitiveness of the Irish manufacturing sector, particularly in industries dominated by multinational companies (Baccaro and Simoni 2002). Also, social partnership has proved remarkably resilient to changes in both business cycles and the political composition of governmental coalitions. At the time of writing, the social partners are engaged in negotiations for a new agreement. The Irish labour market is close to full employment now, and this makes bargaining centralization more difficult than in the past. Despite these new challenges, it looks as though social partnership will continue in the near future.

\section{Italy}

During the 1990s, Italian policy-making followed a similar path to that of the Irish. After a few short-lived attempts in the late 1970s and early 1980s, the Italian concertation began in 1992. In July of that year a shared sense of impending economic crisis pushed the government, the three main union confederations (CGIL, CISL and UIL), and the major employer association, Confindustria, to sign an anti-inflationary agreement that abolished wage indexation and introduced a one-year moratorium on firm-level wage negotiations. This agreement was especially important because the abolished wage indexation mechanism (the so-called scala mobile) had a high symbolic value in Italy (Locke 1994).

In July 1993, a new tripartite agreement confirmed the abolition of wage indexation and introduced national-level wage consultations (in May and September) to link wage increases to the government's macroeconomic targets as stated in the yearly budget law. Unlike the 1992 agreement, which temporarily banned plant-level bargaining, the new agreement introduced a new architecture of nested collective bargaining — at both the industry (every two years) and the plant/territorial levels (every four years). This represented an important victory for the union movement, since the employers had pushed for a single locus of collective bargaining.

In 1995, government and the three confederal unions (but not Confindustria) negotiated a structural reform of the pension system - the most sizeable component of the Italian welfare state. Pension benefits were no longer to be set as a function of past income, but rather were to be determined in accordance with accumulated social security contributions. In the short term, the reform made access to so-called 'seniority pensions' (a particular type of early retirement scheme) more difficult. The overarching goal of the reform was to reduce pension expenditures, thereby also reducing Italy's budget deficit. 
In 1996 social partnership moved to another area of policy. The tripartite 'Pact for Work' increased labour market flexibility by introducing new forms of contingent work. Owing to opposition from a crucial component of the governmental coalition, the Party of the Communist Refoundation, many regulatory changes were somewhat watered down in Parliament, when the Pact was translated into law. The Pact also sought to promote job creation in crisis areas by favouring the emergence of territorial pacts, i.e. local-level concertation on issues of economic development.

In 1997 government and unions agreed to another pension reform. In fact, the 1995 pension reform would become fully effective only after a long transition period. In the meantime, the more generous rules of the preceding regime would be maintained for older workers. The 1997 pension reform sought to accelerate the transition to the new regime. However, because of parliamentary opposition from the Party of the Communist Refoundation, the new rules could be applied only to white-collar workers.

In December 1998 the three confederal unions, government and the Confindustria signed a so-called 'Christmas Pact'. This pact confirmed the structure of collective bargaining as based on two levels, which had been introduced in 1993. It also confirmed and extended the practice of social concertation. For example, it introduced an obligation for government to consult with the social partners on all social policy issues and, in some cases, even to devolve decision-making authority to the social partners so that they could directly regulate certain issues with no need for government involvement.

In 2002 the government, the Confindustria and two of the major union confederations, CISL and UIL, negotiated the Pact for Italy. The structure of the pact was similar to the Irish tripartite agreements, as it exchanged tax reductions for union acquiescence to more flexible regulation of dismissals. This agreement was highly contested, however. The largest union confederation, the CGIL, refused to sign the accord and mobilized workers in opposition. In spite of mounting opposition, the new centre-right government (elected in 2001) decided to go ahead.

As stated in the Italian Ministry of Labour's recent White Book, the centre-right government, elected in 2001, remains committed to a policy of 'social dialogue' and is willing to abstain from direct regulation if the social partners reach consensus among themselves. However, it is also ready to implement its own reform plans, should consensus not be reached (Biagi et al. 2002: 56-9). So far this new strategic orientation has brought about partial agreements, that is, agreements involving only two of the three major union confederations. Whether tripartite policy-making can continue in this abridged form, or whether growing inter-union tensions will eventually lead to its demise remains to be seen.

While less economically successful than the Irish social partnership, the Italian concertation none the less played an important political economic role. Thanks to concertation, in fact, the Italian political economic authorities were able, first, to pull the country out of a difficult socio-political crisis, 
and then to rally the necessary popular consensus needed to qualify for the second phase of the European Monetary Union (EMU) (Salvati 2000: 83-107; Modigliani et al. 1996: 45-90). Because of its politically divided union confederations, lack of coercive control of the peak levels over the peripheral structures, and endemically high levels of workplace-level conflict, Italy has constantly been ranked at the bottom of the various indexes of corporatism (see Dell'Aringa and Lodovici 1992: 33). In Ireland, too, the organizational and political conditions leading to the emergence and reproduction over time of peak-level bargaining, particularly a strong and cohesive labour movement with a high degree of 'authoritative centralization' (Hardiman 1988: 3), appeared to be missing. Absent centralized organizational capacities, both countries developed alternative, but equally effective, mechanisms of inter-organizational co-ordination. The next section analyses these coordination mechanisms.

\section{Co-ordination through aggregative and deliberative mechanisms}

The Irish and Italian industrial relations systems differ from the corporatist ideal type, but also are quite different from one another. The Irish system is close to the Anglo-Saxon model of voluntaristic collective bargaining between unions and employers, mostly at the company level. The Italian system, instead, has historically been characterized by much greater intervention of the state in defining basic worker rights and regulating working conditions. Also, Italy's most important collective bargaining level is the industry level.

With 52 unions affiliated to the ICTU and 59 affiliated to the CGIL, CISL and UIL in 1995, the Irish and Italian labour movements are quite fragmented. ${ }^{3}$ In both countries, workers can choose among multiple unions. Workplace representation structures are generally strong and are based on elected representatives accountable to their members (as well as non-members in Italy). Also, the peak levels do not have formal coercive power over their affiliate unions, except through the threat of expulsion. In Ireland, authoritative centralization is made more complicated by the decentralized structure of collective bargaining. In other words, wage guidelines negotiated at the national level have to be incorporated in collective agreements at company level (in the manufacturing sector) to become effective (Gunnigle et al. 1999: 188). The ICTU has no formal way of ensuring that these contracts comply with the general guidelines. In Italy union structures at all levels are statutorily free to negotiate their own terms and conditions with the appropriate bargaining counterparts.

Corporatist theory emphasizes organizational concentration and vertical control within trade unions as structural preconditions for negotiated policymaking. In light of these premises, the Irish and Italian representation structures appear too weak and fragmented for concertation to emerge and reproduce itself over time. Yet corporatist theory focuses on hierarchy only 
as a co-ordination mechanism. This implies that national pacts should be unlikely to emerge (except sporadically and by fits and starts) in countries where union leaders lack the capacity to impose on workers a series of outcomes they would not necessarily subscribe to.

Hierarchy is, however, one possible mechanism of co-ordination perhaps the most widely diffuse, but not the only possible one. Democracy is also a powerful mechanism of co-ordination and dispute resolution. Compared with hierarchy, democracy also produces legitimacy, i.e. a belief in the validity of a particular collective decision and a willingness to comply with it even in the absence of sanctions or material incentives (Weber 1978: chapter $10)$. Both the Irish and Italian labour movements heavily relied on democratic decision-making procedures. These procedures increased inter- and intra-organizational co-ordination through two different mechanisms, aggregative and deliberative (see Table 1).

The aggregative mechanism of co-ordination has to do with the aggregation of worker preferences through voting. In both Ireland and Italy, union policy decisions were based on the results of workplace ballots. This procedure increased the acceptability of contested collective decisions. In fact, unions that disagreed with the policies of the central confederations voluntarily complied with the will of the majority. From a functional perspective, majority decisions generated the same degree of internal cohesion as a highly centralized association would impose on its branch-level affiliates. As to the reasons why unions decided to comply, the literature on social psychology has underscored procedural justice, namely the willingness to go along with unfavourable collective decisions when the process is perceived to be fair (Lind and Tyler 1988). A union representative provided another explanation for compliance: unions realized that, if they violated the principle of majority decisions at the confederate level, they would encourage similar behaviour from their own internal opposition (interview with Patricia O'Donovan, former deputy secretary general of the ICTU, Geneva, 9 April 2001).

The deliberative mechanism of co-ordination is associated with persuasive communication. In both Ireland and Italy, union leaders did not just ask

TABLE 1

Aggregative and Deliberative Mechanisms of Union Co-ordination

\begin{tabular}{|c|c|c|}
\hline & $\begin{array}{l}\text { Horizontal } \\
\text { (Inter-Union) } \\
\text { Co-ordination }\end{array}$ & $\begin{array}{l}\text { Vertical } \\
\text { (Intra-Union) } \\
\text { Co-ordination }\end{array}$ \\
\hline $\begin{array}{l}\text { Aggregative } \\
\text { Mechanism }\end{array}$ & $\begin{array}{l}\text { Unions losing the vote accept } \\
\text { the will of the majority }\end{array}$ & $\begin{array}{l}\text { Plants or worker groups } \\
\text { losing the vote accept the will } \\
\text { of the majority }\end{array}$ \\
\hline $\begin{array}{l}\text { Deliberative } \\
\text { Mechanism }\end{array}$ & $\begin{array}{l}\text { (Unions influence the } \\
\text { preferences of other unions } \\
\text { through discourse) } \\
\text { (Not observed empirically) }\end{array}$ & $\begin{array}{l}\text { Union leaders influence the } \\
\text { preferences of workers } \\
\text { through discourse }\end{array}$ \\
\hline
\end{tabular}

(C) Blackwell Publishing Ltd/London School of Economics 2003. 
workers to vote: they preceded the vote with workplace assemblies in which they sought to persuade their members that the solutions they proposed were in their best collective interests. Both union movements found that persuasive communication influenced members' preferences, particularly when communication issued from workplace (as opposed to national) leaders (Baccaro 2002a: 424-7). They also noticed that, when not enough attention was paid to communicative processes, the results of the workers' vote were much less positive than expected. The next section returns to the Irish and Italian cases. The emphasis is now on internal processes, and the section illustrates how aggregative and deliberative mechanisms increased internal cohesion and coordination in these two countries' labour movements.

\section{The internal politics of social partnership}

\section{Ireland}

The first social partnership agreement, the PNR, was the most politically contested, and hence the most difficult of all. Employers feared a return to the ineffectual negotiations of the 1970s, which (owing to the combination of centralized and decentralized bargaining) had proved unable to secure wage moderation (Irish Times, 8 October 1987). They had to be dragged into the deal by the determination of the government to have a national agreement.

The Fianna Fail government was a minority government. Even though the major opposition party, Fine Gael, had promised to support the government's economic policies if they were in line with its own policies, securing a tripartite deal was nonetheless very important for this government, as it reduced the risk of political backlash. ICTU leaders were favourably inclined towards the PNR. They were afraid that the government might respond to the economic crisis by following the example of Thatcher's Britain and engaging in a massive attack on union prerogatives. In particular, the ICTU regarded the emergence of the new party of Progressive Democrats, a splitoff from Fianna Fail, and its surprising electoral performance (11.8 per cent of the votes in 1987) as worrisome signs that Ireland might indeed follow the route of Britain (interviews with Bill Attley, former general secretary of the FWUI (first) and SIPTU (later), Bundoran, 3 July 2001, and David Begg, general secretary of the ICTU, Bundoran, 4 July 2001). Public-sector unions, in particular, feared that they would fare especially poorly in free-for-all bargaining, given the government's determination to cut current expenditures (interview with Peter McLoone, General Secretary of IMPACT, Bundoran, 4 July 2001). Also, ICTU leaders were dissatisfied with the outcomes of the previous phase of decentralized collective bargaining between 1980 and 1987, when they had pushed for high nominal wage increases and wound up with lower real take-home pay because of the joint effects of high inflation and fiscal drag. These leaders welcomed the opportunity to negotiate gross pay 
and taxation simultaneously (interview with Peter Cassels, former general secretary of the ICTU, Bundoran, 4 July 2001).

The various unions affiliated to the ICTU had, however, mixed feelings. The craft unions (representing mostly skilled workers in the private sector) were against the PNR as they thought free-for-all bargaining would be more advantageous for them. IDATU, at that time the largest union among distribution workers with about 20,000 members, also opposed the agreement. This union proposed to address the economic crisis by launching a massive job creation scheme sponsored by the state, by increasing taxation on companies and by refusing to pay interests to foreign lenders (Irish Times, 9 November 1987).

Among general unions, both the ITGWU and the FWUI (140,000 and 60,000 members, respectively) supported the deal. ${ }^{4}$ The third largest general union, the British-based ATGWU (23,000 members), was adamantly opposed. Public-sector unions also generally favoured the agreement. However, the executive committee of the LGPSU (local government and public services) recommended rejection to its members (Irish Times, 19 October 1987). This union believed that the PNR deal did not adequately protect public-sector jobs and could even be perceived as union endorsement of public sector cuts (Irish Times, 2 November 1987). However, about 60 per cent of the LGPSU members eventually voted in favour of the PNR agreement.

The ICTU decision-making process follows a series of procedural steps. Prior to engaging in national talks, the confederation summons a convention of all affiliate unions. These unions generally do not ballot their members at this point; instead, the executive of each union reaches a decision and then votes accordingly in the so-called 'Special Delegate Conference'. The distribution of votes is biased in favour of smaller unions. ${ }^{5}$ Generally, unions have little problem authorizing the beginning of negotiations (even though there have been cases in which such authorization has been denied), but they might have greater problems with approval. When negotiations are concluded, the confederation summons another convention to decide about ratification or rejection. At this point, some of the smaller unions convene a meeting of members. Other unions base their decisions on the vote of the executive council. The larger unions in particular ballot their members (e-mail exchange with Donal Nevin, former general secretary of the ICTU, 10 July 2002). The number of unions balloting their members seems to have increased over time. In fact, the ICTU encouraged its affiliates to do so (interview with Patricia O'Donovan, former deputy secretary general of the ICTU, Geneva, 9 April 2001). In case of ballot, the executive of the union may decide to send members a recommendation to vote in a particular way, favourable or negative. In some cases, however, no recommendation is made.

The electoral rule within ICTU is very similar to the procedure used to elect the American president. In other words, if more than 50 per cent of voters choose to endorse or reject the proposed agreement, all delegates of 
that union vote for that option in the national convention. Similar to the American presidency, this rule implies that the union confederation may democratically choose to pursue a policy that is supported by less than the majority of the workers (if approval is by close margins and rejection by larger margins). This may have happened in 1987 even though the data of the various union elections are not available to validate this claim. Similar to the American case, this possibility does not detract from the legitimacy of whatever decision is reached within the union convention. Unions that lose do not normally secede from the confederation and pursue their own independent wage policy, as they would be free to do; instead, they abide by the will of the majority.

Most of the 56 unions attending the 1987 special conference on PNR voted against the agreement. The ITGWU, the largest union, conducted a ballot among its members to decide how to cast its vote. The result of the vote was very close but favourable. One of the key actors remembers that 97,000 votes were cast and the difference was 400 votes (interview with Bill Attley, former general secretary of the FWUI and SIPTU, Bundoran, 3 July 2001). The Irish Times (20 November 1987) wrote that the ITGWU ballot 'resulted in a very small majority in favour of endorsing the programme'. With 48 delegates, the vote of the ITGWU was decisive. In fact, the PNR was approved with a majority of 181 votes to 114 . The second largest general union, the FWUI, also voted in favour, and so did most of the public-sector unions, including two out of three of the teachers' unions (Irish Times, 20 November 1987). Had the ITGWU members voted against, however, the PNR would have never passed.

The losing faction decided to fight its battle from inside the trade union congress rather than from outside. In 1989, when the inflation rate surpassed the 2.5 per cent increase included in the national agreement, the MSF (a skilled white-collar union) and the ATGWU, both British-based (i.e. with headquarters in Britain), called for a special ICTU conference to decide whether the confederation should withdraw from partnership (Irish Times, 26 September, 9 October and 25 November 1989). Since talks were already underway for a renewal of the PNR, this vote would de facto also determine whether or not the experience of national bargaining would be continued in the future. The motion to withdraw was rejected, with 181 votes against and 141 in favour. Once again, the favourable vote of the general union SITPU and of the public-sector unions was decisive (Irish Times, 9 February 1990).

Approval of the other partnership agreements proved to be less complicated than the PNR. As the economy got back on track, the combination of low inflation and tax cuts brought about benefits for most categories of workers. In February 1991 the PESP was ratified with 224 votes in favour and 109 against. In March 1994 the PCW was ratified with a 256 to 76 margin. Only eight unions voted against the PCW, among these some of the usual suspects like ATGWU and MSF.

Ratification of the P2000 agreement turned out to be more difficult than might have been expected, since the economy was booming by 1996. The 
ICTU-wide vote was 217 for and 134 against. Quite surprisingly, MSF, one of the staunchest opponents of social partnership, cast its votes in favour. For the first time, this union decided to ballot its members. In spite of a recommendation issued by the union's executive council to vote against the agreement, the rank-and-file approved by 60 per cent. Apparently, they appreciated the sizeable tax relief that was incorporated in the accord (Irish Times, 25 January 1997).

With the P2000 agreement, the process of union ratification became an integral part of the broader political game. When it became clear that P2000 was in danger because SIPTU, the largest union, might be unable to deliver its votes, the government cut a last-minute deal with one of the teacher's unions to secure its 17 votes. The deal involved promotions for 3,000 primary school teachers, the union's constituency (Irish Times, 28 January 1997). In the end, SIPTU voted for the agreement, but the result of the union's internal ballot was quite tight, with 65,000 votes in favour and 55,000 against. Interestingly enough, this tight outcome seemed to have little to do with the content of the agreement and more with its process (or lack thereof). Because the agreement was finalized over Christmas, and because union leaders wanted the provisions contained in the pact to affect the Budget for 1996 (which was issued at the end of January), they had to hasten the process of ratification and were able to devote only three weeks to it. In other words, union leaders did not have enough time to explain the contents of the agreement to their members (interview with John McDonnell, General Secretary of SIPTU, Dublin, 6 September 2001) This contrasted with a well orchestrated Campaign against Partnership 2000, which was particularly strong within SIPTU.

The SITPU leaders learned from their own mistakes, however. They entered into negotiations for the PPF with a very intense consultation process that directly involved the members in setting up the union's bargaining agenda. When time for ratification came, they allowed the longest time ever for the election campaign - three to four weeks for the circulation of information and for consultative meetings, and then three to four weeks more for the organization of the ballot (interview with John McDonnell, Dublin, 6 September 2001). The consultative process relied extensively on the persuasive capacities of the shop stewards (interview with Seamus Sheils, editor of the SIPTU journal, Bundoran, 5 July 2001). As a result, almost 70 per cent of the workers voted in favour, the highest score ever for the union. The PPF was approved by the ICTU as a whole with 251 votes for and 112 against.

\section{Italy}

The internal politics of the Italian concertation bear remarkable similarities to the Irish case. ${ }^{6}$ In this country, too, the unions used democratic procedures, particularly nationwide worker referenda, to reduce internal conflict and bring about support from within their own ranks. When these procedures were not followed (e.g. in 1992 and 2002), national agreements met with 
worker protests and grass-roots mobilizations and appeared therefore less stable.

The 1992 tripartite agreement (much like the Irish 1987 agreement) was an emergency deal. Italy's macroeconomic and financial conditions had deteriorated considerably in the late 1980s-early 1990s. Economic crisis was accompanied by an equally serious political crisis. In 1992 the Milanese judiciary initiated the so-called 'Mani Pulite' investigation into political corruption. This investigation quickly escalated and eventually led to the dismantling of both the Christian Democratic and the Socialist Parties, the two major governmental parties in postwar Italy. By abolishing wage indexation, the 1992 agreement sought to send a signal to international financial markets that the lira's nominal exchange rate parity would be easier to defend in the future (because Italy's inflation rate would be more closely aligned with the inflation rates prevailing in the rest of European Monetary System). This agreement was, however, insufficient to prevent a major financial crisis. Misgivings about sustainability of the lira's parity led to a run on the currency in September 1992. The lira was devalued and forced to exit (temporarily) the EMS.

The 1992 agreement was well received by the Italian employers. But it provoked a major crisis in the unions, especially the CGIL. The autumn of 1992 witnessed numerous demonstrations against the accord. Various factory councils in the North established a movement of so-called 'autoconvocati' (the self-summoned) to contest the abolition of wage indexation and the block on plant-level bargaining. Prominent within these demonstrations were members of the militant metalworkers unions as well as employees of chemical and textile factories which were generally considered to be more moderate union members (interviews with Tino Magni, Secretary General of the FIOM-Lombardy, Sesto San Giovanni, 3 June 1997, and Savino Pezzotta, Secretary General of the CISL Lombardy, Milan, 10 June 1997).

Protesters focused their complaints not so much on the content of the agreement, which they rejected, as on the decision-making process. This is reflected in the final document approved by the National Assemblies of the Self-Summoned Delegates (Meta, no. 11, November 1992, p. 32). Because the agreement had not been preceded by a consultation among the workers affected, it was regarded as unrepresentative of the will of the working people by these dissenting groups. The timing of the accord - signed on 31 July, that is, the day before the beginning of summer holidays in most industrial factories - was perceived as especially offensive by many workers, and even as deliberately designed to pre-empt rank-and-file opposition.

Unlike its 1992 analogue, the July 1993 agreement was preceded by a binding referendum among the workers - a first in the history of the Italian labour movement. Remembering the grass-roots mobilizations that had taken place one year earlier, the confederal leaders asked for and obtained from their bargaining counterparts sufficient time to organize a consultation of the rank-and-file workers. In fact, although the tentative agreement between government, employers and union leaders was reached on 3 July 1993, the actual agreement was not signed until 23 July. In the intervening 20 days, the unions 
set up approximately 30,000 assemblies in the country's major plants and offices. About 1.5 million workers participated in the vote and 68 per cent of them approved the deal. The consultation identified large pockets of dissent. For example, the employees of some historic automotive plants, like Alfa Arese near Milan, Mirafiori in Turin and OM Iveco in Brescia, voted against the accord, sometimes overwhelmingly.

Unlike previous times, when the opposition and spontaneous mobilization of large industrial factories in northern Italy had quashed attempts at reform (see Golden 1988), this time dissenting groups did not mobilize. Their inaction did not reflect approval of the agreement (Il Sole-24 Ore, 18 June 1993; Il Manifesto, 10 July 1993). They chose not to mobilize because of the peculiar mix of wage restraint and union democracy that was delivered to them with the 1993 accord. The agreement contained, in fact, two important responses to the 'methodological' criticisms previously raised by the autoconvocati movement and other dissident factions. First, it institutionalized the regular election of workplace representatives. Second, it was accompanied by a binding consultation among the workers. Although they clearly frowned on the agreement's content, the dissident groups concentrated their energies not on organizing grass-roots protest, but rather on the electoral process. Some of these groups had, in the end, something to say about this process; a few, for example, complained that 'in the assemblies, only union leaders who were in favour of the agreement [were] allowed to speak' (Il Sole24 Ore, 23 July 1993). Yet none contested the outcome of the consultation, that is, the clear endorsement of the July 1993 agreement by the majority of the Italian workers (Il Manifesto, 23 July 1993).

The process leading to approval of pension reform in 1995 was very similar to that of 1993. Pension reform was as unpopular with the Italian workers as the abolition of wage indexation had been. For this reason, the Italian unions did not even try to negotiate with government behind closed doors, but engaged instead in Italy's largest worker consultation ever. After reaching a tentative agreement with government, the confederal unions organized 42,000 workplace assemblies and a binding referendum. Four and a half million workers and pensioners showed up for the ballot, and 64 per cent of them approved the reform. Pensioners voted overwhelmingly in favour of the accord (91 per cent). Active workers approved the reform as well, albeit with a lower percentage (58 per cent).

Once again, the largest area of dissent was in northern industrial factories. In Lombardy, Italy's richest and most industrialized region, the majority of all active workers rejected the proposed reform. In Piedmont all major industrial categories (metalworkers, chemical workers and textile workers), as well as other worker categories, also rejected the accord. In the metalworking sector, the vast majority of plants with more than 500 employees rejected (often overwhelmingly) the pension accord, especially in Piedmont and Lombardy. Yet, in these same regions, metalworkers employed in small firms (up to 50 employees) approved the agreement. The referendum clearly showed that the choice to engage in pension reform was not just a fiat by union bureaucrats, as had 
sometimes been claimed in the past, but was actually supported by a clear majority of the Italian workers, some of whom (like the public-sector workers) were thus making much larger sacrifices than were the industrial workers.

The process of worker consultation also gave union leaders an opportunity to influence the workers' process of preference formation. Workers relied on union representatives to make sense of the general structure and distributional consequences of the 1995 pension reform and formed their opinions based on the particular way (positive or negative) in which pension reform was presented to them in the assemblies. Factories in very similar structural conditions approved or rejected the pension accord depending on the particular way the problem was framed. Interestingly enough, plant representatives were much more likely to influence workers than were national or regional leaders (Baccaro 2002a: 424-6).

The 1996 Pact for Work and the 1998 Christmas Pact did not have the same immediate distributional consequences as the 1992, 1993 and 1995 accords. They were prospective agreements. The first introduced new typologies of flexible employment; the second confirmed the structure of collective bargaining introduced in 1993. Agreement among the peak leaders of the three confederations was sufficient to mobilize consensus from within the union ranks. The three confederal unions did not feel that they needed to organize worker consultations to stave off possible accusations of illegitimacy.

A referendum was held in 1997 on the second pension reform. The outcome of this consultation was almost a foregone conclusion, since the reform affected only 35 per cent of the workforce (owing to the political constraints imposed by the Party of the Communist Refoundation). The confederations organized 39,000 assemblies followed by a referendum. This time 84 per cent of the 3.1 million voters approved the agreement. Interestingly enough, sectors like banking/insurance and the public sector, predominantly populated by white-collar workers, voted in favour of the agreement. Yet the 1997 reform further delayed access to retirement for workers in these sectors.

The 2002 agreement was different from the others. The CGIL did not agree on the content, and perhaps not even on the desirability, of a new national deal, and mobilized workers in protest. This was not the first time that the three confederations had departed from unity of action. A similar episode had occurred in 1984 as well (Baccaro 2000c, pp. 585-7). The CGIL's peak leadership asked for a worker referendum on the 2002 Pact for Italy and declared it was ready to be bound by its results (La Stampa, 8 July 2002). As in 1984, however, this referendum was never organized. The 2002 worker mobilizations were among the largest in Italy's postwar history — so large that the future of the Italian concertation appears uncertain.

\section{Non-corporatist concertation?}

In the past decades, Ireland and Italy have witnessed different forms of policy-making, concerted and non-concerted; yet their interest representation 
structures have remained more or less the same (Roche and Ashmore 2001; Baccaro 2002b). Clearly, the same organizational structures are compatible with different policy processes. This does not mean that the organizational side of concertation is irrelevant. In fact, as illustrated by the Irish and Italian cases, building sufficient internal consensus for centralized policies remains a key problem. In both Ireland and Italy, the peak union leaders agreed among themselves on the need to engage in central negotiations (in Italy until 2001). This favourable attitude by the peak levels was key to get concertation going. However, not all worker groups, nor even all middle-level leaders inside the union confederations, shared the peak levels' positive attitude. Some vehemently opposed concerted policy-making.

In 1987, most Irish unions were against social partnership, as revealed by the way they voted in the ICTU convention. In 1989-90, an even larger coalition of Irish unions sought again to bring social partnership to an end. In 1992, the Italian confederal leaders' decision to abolish wage indexation without consulting their membership met with vehement (and at times even violent) rank-and-file contestation; the worker demonstrations of 2002, which were prompted by a failure to consult Italian workers, provide further illustration of the importance of inter- and intra-union consensus for stable concertation regimes.

These latent internal tensions did not lead to the collapse of social partnership in Ireland and Italy, but they might have done. They did not, because both the Irish and Italian labour movements found ways to manage them. Far from insulating themselves from their constituents and strengthening their capacity to impose controversial deals, the Irish and Italian union leaders relied instead on democratic decision-making procedures to build consensus within their ranks. In other words, union leaders retained the privilege of proposing particular solutions to their constituents, but workers had the power to accept or reject them.

Democratic decision-making had both aggregative and deliberative effects. Powerful groups within the unions, which objected to the content of the various agreements, felt compelled to go along with the will of the majority - which constituted the aggregative mechanism. This feeling of moral obligation was well expressed by a representative of the ATGWU, a union that voted against all of the Irish social partnership agreements: 'We're very loyal Congress members, I'm afraid. We believe in the whole concept of Congress. We feel that whatever has to be done has to be done from within' (interview with Ben Kerney, Republic of Ireland Secretary of the ATGWU, Bundoran, 3 July 2001). Other union officers expressed similar views (interviews with Jerry Shanahan, Deputy National Secretary of the MSF, Bundoran, 4 July 2001, and with Brendan Archbold, National Official of Mandate, Bundoran, 5 July 2001). Also, democratic procedures gave union leaders an opportunity to influence the workers' process of preference formation through persuasive communication in union assemblies, which constituted the deliberative mechanism. In this regard, an Italian union leader argued that workplace assemblies have the capacity to shift about 20 per cent 
of the workers' vote (interview with Carlo Spreafico, Regional Secretary of the FIM-CISL Lombardy, Milan, 16 June 1997).

Each of the Irish and Italian cases taken individually is sufficient to cast doubt on the theoretical link between concertation and corporatist structure. Taken together, the two cases suggest that there is an alternative, functionally equivalent but more democratic, path to concertative policy-making. In fact, the Irish and Italian interest representation systems are considerably different from one another. The logic of 'political exchange' in the two countries is also very different (Pizzorno 1978). The Irish social partnership entailed a classic quid pro quo between wage moderation and tax reductions. In other words, union acquiescence could be bought, at least in part, through material incentives (Regini 1997: 268). The Italian pacts were, instead, much closer to macro-concessionary bargaining, as they involved little, if any, material compensation for workers. In spite of this diversity, the same causal mechanism is at work in both cases: namely, the use of democratic processes to bring about inter- and intra-organizational co-ordination.

A question this paper was unable to address is whether organizational preconditions have changed over time, that is whether, for reasons to be explored, the concertative agreements of the 1970s-early 1980s worked best with a hierarchical and internally undemocratic structure of unions while the more recent ones are better suited to more open and participatory arrangements (Baccaro 2002b: 349). To the extent that the new concertative agreements involve little material incentives for workers (as in Italy), reliance on legitimating procedures, and on the leaders' capacity to persuade their constituents that sacrifices are just and equally distributed, may have become more important now than in the past, when sacrifices were compensated with benefits in other areas (e.g. more favourable welfare provisions), and it could have been conceivable for leaders simply to show that they were able to deliver the goods for their members, without worrying much about procedural fairness.

\section{Conclusions}

On the basis of the Irish and Italian experiences, this article has argued that concertation can co-exist perfectly with a non-corporatist structure of the interest representation system. Monopolistic, centralized and internally nondemocratic associations are not necessary for concertation to emerge and reproduce itself, even over considerable periods of time. Even relatively fragmented union structures can find alternative, and more democratic, ways of co-ordinating in support of concerted policy-making. In brief, while corporatism as a process appears alive and kicking, corporatism as a structure may be dead.

Ireland and Italy are not the only countries lacking corporatist institutions in which forms of concerted policy have recently emerged, and future research should aim to discover whether or not the internal processes leading to the emergence of negotiated policy-making in these countries resemble the Irish 
and Italian processes. They may not, in which case organizational democracy would be one of the mechanisms, alongside others, through which relatively decentralized labour movements co-ordinate in support of centralized policymaking arrangements.

Even though explaining the emergence of concertation is outside the scope of the paper, a few similarities between the Irish and Italian cases are worth noting. Both the Irish and Italian governments were weak. In 1987 the Irish government was a minority government. In the early 1990s several Italian governments were of 'technocratic' nature, that is, without clear parliamentary majorities to support them. The range of tasks these governments had to accomplish - fiscal adjustment, disinflation and the rekindling of economic and employment growth - was daunting. To increase public acceptance of their policies, both governments found it expedient to rely on trade union agreement and support (Pizzorno 1978; Lehmbruch 1979).

The unions' decision to participate was influenced by the climate of economic emergency prevailing in the two countries (Dore 1994: 10). The Irish and Italian labour movements clearly perceived that something drastic needed to be done to bring the two countries back on track. To avoid adjustment solutions based on labour market deregulation and the scaling down of union prerogatives, solutions that were actively debated in both countries, they agreed to share responsibility for potentially unpopular policies. This allowed them to be directly involved in the formulation of all major economic policies.

In contrast with much recent literature that regards them as key (Swenson 1991; Hall and Soskice 2001: 4; Thelen 2003), organized employers did not play a very important role in the emergence of concertative arrangements in Ireland and Italy. In 1987 the Irish employers opposed re-centralization of bargaining. They believed that decentralized bargaining would be more effective in ensuring wage moderation. Also, they disagreed on specific union demands, like the one-hour reduction in working time to 39 hours per week, or a minimal lump-sum increase for the low-paid. Government had to work hard to persuade them to stay at the bargaining table and sign the deal. The Italian employers too were not especially enthusiastic about concertation. They did not agree, for example, with the two-tiered structure of collective bargaining that was introduced in 1993 and confirmed in 1998. In the case of pension reform, the employers pulled out early in the negotiation process and then refused to sign the final agreement, which therefore became an agreement between government and unions. The employers' attitude towards concertative policy-making appeared to be contingent on economic performance. When it became clear that the Irish concertation was very effective in ensuring wage moderation and boosting profits, the Irish employers changed their initially sceptical attitude. Because Italy's economic performance has been much less remarkable than the Irish in the last few years, the attitude of the Italian employers has been more ambivalent, and of late state-driven deregulation of the labour market has become their preferred policy option. 
While labour and the state were the key actors, just as in the past, the Irish and Italian social pacts were nonetheless very different from the old historical compromises of the 1930s when the unions strategically chose to shift their power from the industrial to the political arena and in so doing acquired the capacity to pursue broadly redistributive goals (Korpi and Shalev 1979). Even though they were not directly designed by business, the systemic consequences of the new pacts had few of the redistributive features generally associated with Scandinavian corporatism. In Ireland, for example, the wage share of GDP declined from 71 to 56.9 per cent of GDP between 1987 and 2000 (European Commission 2000: table 32). The unions' role in the new social pacts was to participate in enhancing national competitiveness (Rhodes 1998). In exchange, the unions gained access to policy-making. This enabled them to check the distributional consequences of policies and limit the impact on the weakest segments of society. Whether this is the best that labour can do at this point in time, given systemic constraints, is a question this paper cannot address, but one that unions and the left should seriously consider, as their future would seem to be crucially dependent on it.

Final version accepted 24 July 2003.

\section{Acknowledgments}

Many thanks to John Gibson and Irene Stevenson for granting me access to the Irish Times' archive in Dublin, and to all the people who agreed to be interviewed. The views expressed in this article are my own and do not necessarily reflect those of the organization with which I am affiliated.

\section{Notes}

1. The remainder of this section draws on Baccaro (2002b: 331-2).

2. The corporatist literature also devoted some scholarly attention to the party composition of governments. The main conclusion was that successful wage restraint required social democratic or at least consociational governments in power (see Schmitter 1981; Crouch 1985). The organizational characteristics and strategic choices of business remained, with some notable exceptions (e.g. Streeck 1984), outside the main focus of the analysis. It was only later, and especially after the decision of the Swedish metalworking employers to break the pattern of centralized negotiations in Sweden in 1983, that employers were brought back into the picture (Swenson 1991; Pontusson and Swenson 1996; Hall and Soskice 2001: 4).

3. The ICTU is, however, less fragmented than is suggested by these numbers. In 1996, ten unions with more than 15,000 members accounted for almost 80 per cent of trade union membership (Gunnigle et al. 1999: 129-30). The largest union, the Services, Industrial, Professional and Technical Union (SIPTU), accounted for 42 per cent of total union membership in the first half of the 1990s (Roche et al. 2000: 
table IR.12). Also, the ICTU reduced its internal fragmentation by promoting union mergers in the 1980s and 1990s (Roche and Ashmore 2001: table 5).

4. These two unions merged in 1990 and formed SIPTU, another general union.

5. According to the ICTU electoral rules (last modified in 1991), a union with up to 2,000 members is allotted two votes, while a union with up to 201,000 members is allotted 76 votes (see ICTU 1997: section 4, pp. 7-8).

6. This section draws on Baccaro (2000c: 591-6; and 2002a: 420-4).

\section{References}

Baccaro, L. (2002a). 'Negotiating the Italian pension reform with the unions: lessons for corporatist theory'. Industrial and Labor Relations Review, 55: 413-31.

(2002b). 'The construction of "democratic" corporatism in Italy'. Politics \& Society, 30: 327-57.

(2002c). 'Centralized collective bargaining and the problem of "compliance": lessons from the Italian experience'. Industrial and Labor Relations Review, 53: 579-601.

and Simoni, M. (2002). "The Irish Social Partnership and the "Celtic tiger" phenomenon'. Unpublished paper, International Institute for Labour Studies, Geneva.

Berger, St. and Compston, H. (eds) (2002). Policy Concertation and Social Partnership in Western Europe. New York and Oxford: Berghahn Books.

Berger, Su. (ed.) (1981). Organizing Interests in Western Europe. New York: Cambridge University Press.

Biagi, M. et al. (2002). 'White paper on the labor market in Italy'. Bulletin of Comparative Labour Relations, 44: 1-117.

Cawson, A. (1986). Corporatism and Political Theory. Oxford: Blackwell.

Compston, H. (2002). 'The strange persistence of policy concertation'. In S. Berger and H. Compston (eds), Policy Concertation and Social Partnership in Western Europe. New York and Oxford: Berghahn, pp. 1-16.

Crouch, C. (1985). 'Conditions for trade union wage restraint'. In L. N. Lindberg and C. S. Maier (eds), The Politics of Inflation and Economic Stagnation. Washington, DC: Brookings Institution, pp. 105-39.

Dell'Aringa, C. and Samek Lodovici, M. (1992). 'Industrial relations and economic performance'. In T. Treu (ed.), Participation in Public Policy-Making. Berlin: De Gruyter.

Dore, R. (1994). 'Incomes policies: why now?' In R. Dore, R. Boyer and Z. Mars (eds), The Return to Incomes Policies. London: Pinter, pp. 1-31.

European Commission (2000). European Economy. Brussels: Directorate for Economic and Financial Affairs, no. 71.

Fejertag, G. and Pochet, P. (eds) (1997). Social Pacts in Europe. Brussels: ETUI. $\longrightarrow$ and - (eds) (2000). Social Pacts in Europe: New Dynamics. Brussels: ETUI.

Golden, M. (1988). Labor Divided: Austerity and Working-Class Politics in Contemporary Italy. Ithaca, NY: Cornell University Press.

- (1993). 'The dynamics of trade unionism and national economic performance'. American Political Science Review, 87: 439-54.

Goldthorpe, J. H. (ed.) (1984) Order and Conflict in Contemporary Capitalism. Oxford: Clarendon Press.

Gunnigle, P., McMahon, G. and Fitzgerald, G. (1999). Industrial Relations in Ireland: Theory and Practice. Dublin: Gill \& Macmillan.

(C) Blackwell Publishing Ltd/London School of Economics 2003. 
Hall, P. A. and Soskice, D. (2001). 'An introduction to varieties of capitalism'. In P. A. Hall and D. Soskice (eds), Varieties of Capitalism. Oxford: Oxford University Press, pp. 1-68.

Hardiman, N. (1988). Pay, Politics, and Economic Performance in Ireland 1970-1987. Oxford: Clarendon Press.

ICTU (1997). 'Constitution and standing orders'. Dublin: ICTU, July.

Iversen, T. (1999). Contested Economic Institutions. New York: Cambridge University Press.

Katz, H. (ed.) (2004). Tripartite Dialogue and Social Policy: Essential or Irrelevant. Ithaca, NY: Cornell University Press, forthcoming.

Katzenstein, P. J. (1985). Small States in World Markets: Industrial Policy in Europe. Ithaca, NY: Cornell University Press.

Korpi, W. and Shalev, M. (1979). 'Strikes, industrial relations and class conflict in capitalist societies', British Journal of Sociology, 30: 164-87.

Lange, P. (1983). 'Politiche dei redditi e democrazia sindacale in Europa occidentale'. Stato e Mercato, 3: 425-74.

Lehmbruch G. (1979). 'Liberal corporatism and party government'. In P. Schmitter and G. Lehmbruch (eds), Trends towards Corporatist Intermediation. London: Sage, pp. 147-83 (first published in Comparative Political Studies, 10, 1977).

and Schmitter, P. (eds) (1982). Patterns of Corporatist Policy-Making. Beverly Hills: Sage.

Lind, E. A. and Tyler, T. R. (1988). The Social Psychology of Procedural Justice. New York: Plenum Press.

Locke, R. M. (1994). 'L'abolizione della scala mobile'. In C. Mershon and G. Pasquino (eds), Politica in Italia, vol. 9. Bologne: Il Mulino, pp. 233-45.

Modigliani, F., Baldassarri, M. and Castiglionesi, F. (1996). Il miracolo possible:un programma per l'economia italiana. Bari: Laterza.

Molina, O. and Rhodes, M. (2002). 'Corporatism: the past, present, and future of a concept'. Annual Review of Political Science, 5: 305-31.

O'Donnell, R. (2001). 'Towards post-corporatist concertation in Europe?' In H. Wallace (ed.), Interlocking Dimensions of European Integration. London: Pinter, pp. 305-22.

— and O'Reardon, C. (1997). 'Ireland's experiment in social partnership, 1987-96'. In G. Fejertag and P. Pochet (eds), Social Pacts in Europe. Brussels: ETUI: 79-95.

and - (2000). 'Social Partnership in Ireland's economic transformation'. In

G. Fejertag and P. Pochet (eds), Social Pacts in Europe: New Dynamics. Brussels: ETUI, pp. 237-56.

Offe, C. (1981). 'The attribution of public status to interest groups: observations on the West German case'. In S. Berger (ed.), Organizing Interests in Western Europe. New York: Cambridge University Press, pp. 123-58.

Panitch, L. (1979). 'The development of corporatism in liberal democracies'. In P. Schmitter and G. Lehmbruch (eds), Trends towards Corporatist Intermediation. London: Sage, pp. 119-45.

Pizzorno, A. (1978). 'Political exchange and collective identities'. In C. Crouch and A. Pizzorno (eds), The Resurgence of Class Conflict in Western Europe since 1968. London: Macmillan, pp. 277-98.

Pontusson, J. and Swenson. P. (1996). 'Labor markets, production strategies, and wage bargaining institutions: the Swedish employer offensive in comparative perspective'. Comparative Political Studies, 29: 223-50. 
Regini, M. (1984). 'The conditions for political exchange: how concertation emerged and collapsed in Italy and Great Britain'. In J. H. Goldthorpe (ed.), Order and Conflict in Contemporary Capitalism. Oxford: Clarendon Press, pp. 124-42.

(1997). 'Still engaging in corporatism? Recent Italian experience in comparative perspective'. European Journal of Industrial Relations, 3: 259-78.

Rhodes, M. (1998). 'Globalization, labour markets and welfare states: a future of "competitive corporatism"?' In M. Rhodes and Y. Mény (eds), The Future of European Welfare. London: Macmillan, pp. 178-203.

Roche, W. K. (1997). 'Pay determination, the state and the politics of industrial relations'. In T. Murphy and W. K. Roche (eds), Irish Industrial Relations in Practice. Revised and Expanded Edition. Dublin: Oak Tree Press, pp. 145-226.

and Ashmore, J. (2001). 'Irish unions in the 1990s: testing the limits of social partnership'. In G. Griffin (ed.), Changing Patterns of Trade Unionism. Sidney: Criterion.

and Geary, J. F. (2000). " "Collaborative production" and the Irish boom: work organization, partnership and direct involvement in Irish workplaces'. Economic and Social Review, 31(1): 1-36.

— with Larragy, J. and Ashmore, J. (2000). 'Ireland'. In B. Ebbinghaus and J. Visser (eds), The Societies of Europe: Trade Unions in Western Europe since 1945. London: Macmillan, pp. 339-69.

Salvati, M. (2000). Occasioni mancate: Economia e politica in Italia dagli anni '60 a oggi. Bari: Laterza.

Schmitter, P. (1979). 'Still the century of corporatism?' In P. Schmitter and G. Lehmbruch (eds), Trends towards Corporatism Intermediation. London: Sage, pp. 7-49 (first published in Review of Politics, 36, 1974).

-(1981). 'Interest intermediation and regime governability in contemporary western Europe and North America'. In S. Berger (ed.), Organizing Interests in Western Europe. New York: Cambridge University Press, pp. 285-327.

(1982). 'Reflections on where the theory of corporatism has gone and where the praxis of neo-corporatism may be going'. In G. Lehmbruch and P. Schmitter (eds), Patterns of Corporatist Policy-Making. London: Sage, pp. 259-90.

-(1983). 'Teoria della democrazia e pratica neo-corporativa'. Stato e Mercato, 9 (December): 385-423.

—and Lehmbruch, G. (eds) (1979). Trends towards Corporatist Intermediation. London: Sage.

Schreiner, G. (1994). 'Beyond corporatism: towards new forms of public policy formulation in South Africa'. Transformation, 23: 1-22.

Schumpeter, J. A. (1950). Capitalism, Socialism and Democracy. New York: Harper \& Row.

Streeck, W. (1982). 'Organizational consequences of corporatist cooperation in West German labor unions'. In G. Lehmbruch and P. Schmitter (eds), Patterns of Corporatist Policy-Making. Beverly Hills, Sage, pp. 29-82.

(1984). 'Neo-corporatist industrial relations and the economic crisis in West Germany'. In J. H. Goldthorpe (ed.), Order and Conflict in Contemporary Capitalism. Oxford: Clarendon Press, pp. 291-314.

(1994). 'Einleitung des Herausgebers: Staat und Verbände: Neue Fragen. Neue Antworten?' Politische Vierteljahresschrift, 25: 7-34.

Swenson, P. (1991). 'Bringing capital back in, or Social democracy reconsidered: employer power, cross-class alliance, and centralization of industrial relations in Denmark and Sweden'. World Politics, 43: 513-44. 
Tarantelli, E. (1986). Economia politica del lavoro. Turin: Utet.

Thelen, K. (2003). 'The political economy of business and labor in the developed democracies'. In I. Katznelson and H. Milner (eds), Political Science: The State of the Discipline. New York: W. W. Norton, forthcoming.

Traxler, F., Blaschke, S. and Kittel, B. (2001). National Labour Relations in Internationalized Markets. New York: Oxford University Press.

Visser, J. (1990). 'In search of inclusive unionism'. Bulletin of Comparative Labour Relations, 18.

Weber, M. (1978). Economy and Society (2 vols.). In G. Roth and C. Wittich (eds), Berkley: University of California Press. 
Copyright of British Journal of Industrial Relations is the property of Blackwell Publishing Limited and its content may not be copied or emailed to multiple sites or posted to a listserv without the copyright holder's express written permission. However, users may print, download, or email articles for individual use. 